\title{
The implications of the COVID-19 pandemic for pensions
}

Book or Report Section

Published Version

Creative Commons: Attribution 4.0 (CC-BY)

Open Access

Sutcliffe, C. (2020) The implications of the COVID-19 pandemic for pensions. In: Billio, M. and Varotto, S. ORCID: https://orcid.org/0000-0001-5328-5327 (eds.) A New World Post COVID-19: Lessons for Business, the Finance Industry and Policy Makers. Innovation in Business, Economics \& Finance (1). Ca' Foscari University Press, Venice, Italy, pp. 235-244. ISBN 9788869694424 doi: https://doi.org/10.30687/978-88-6969-442-4/017 Available at https://centaur.reading.ac.uk/92111/

It is advisable to refer to the publisher's version if you intend to cite from the work. See Guidance on citing.

Identification Number/DOI: https://doi.org/10.30687/978-88-6969-442-4/017 <https://doi.org/10.30687/978-88-6969-442-4/017>

Publisher: Ca' Foscari University Press

All outputs in CentAUR are protected by Intellectual Property Rights law, including copyright law. Copyright and IPR is retained by the creators or other copyright holders. Terms and conditions for use of this material are defined in the End User Agreement. 


\section{CentAUR}

Central Archive at the University of Reading

Reading's research outputs online 


\title{
The Implications of the COVID-19 Pandemic for Pensions
}

\section{Charles Sutcliffe}

The ICMA Centre, Henley Business School, University of Reading, UK

\begin{abstract}
COVID-19 and the lockdowns have had a big global economic effect, as well as increasing mortality. We examine the effects of COVID-19 and the resulting relaxations of pension regulations on pension schemes. Those who transfer their pension or withdraw cash from their pension pot while asset prices are depressed by COVID-19 are losers; as are members of defined benefit schemes with a deficit whose employer fails due to COVID-19. The increased mortality from COVID-19 will have a minimal effect on pensions. If economies recover to pre-COVID-19 levels, the long run effects on pensions should be small.
\end{abstract}

Keywords Pensions. COVID-19. Coronavirus. Longevity. Mortality. Lockdown. Pension contributions. Pension transfers. Pension scams. Pension withdrawals. State pensions.

Summary 1 Introduction. - 2 Types of Pension Scheme. - 3 Longevity. - 4 State Pensions. - 5 Asset Values. - 6 Discount Rate. - 7 Companies. - 8 Members. - 9 Regulation. - 10 Conclusions.

\section{Introduction}

The COVID-19 pandemic and the associated lockdown has had big negative effects on national economies - sharply reduced gross national product (GNP), depressed share prices, considerably increased unemployment, forced firms into liquidation, reduced interest rates, lowered government tax revenues, and caused very large amounts of government spending. The economic consequences of COVID-19 have affected pension schemes in a variety of ways. In addition, COVID-19 has led to the death of hundreds of thousands of people globally, which also has implications for pension schemes and annuity providers.

Innovation in Business, Economics \& Finance 1

ISBN [ebook] 978-88-6969-442-4 


\section{Types of Pension Scheme}

There are two main types of pension scheme - defined benefit (DB) and defined contribution (DC) (Sutcliffe 2016). DB schemes are offered by employers (sponsors), and promise to pay a pension calculated using either a member's final or average salary, and the number of years of membership of the scheme (accrued years). Both the employer and members make contributions which are a percentage of the member's salary. This money is then invested in a pooled manner by the DB scheme to provide the cash to pay the promised pensions. Every year (or every three years in the UK) each DB scheme undergoes an actuarial valuation when the assets are compared with the present value of the scheme's liabilities, i.e. the promised pensions. This may lead to a change in both the member and employer contribution rates, although the ultimate responsibility for meeting the pensions promise lies with the employer.

DC schemes receive contributions from both the members and their employer, and this money is paid into segregated pots of money, each 'owned' by the member concerned. Members can usually choose how their pot of money is invested (although the vast majority do not), and when they retire they choose what to do with the final value of their pot of money - buy an annuity, take it in cash, or go into drawdown (i.e. invest the money and make withdraws as required).

The relative importance of DB and DC schemes in terms of assets and accrued liabilities differs between countries, as shown in table 1.

Table 1 asset split between DB and DC occupational schemes and total assets in 2019 (Willis Towers Watson 2020b)

\begin{tabular}{lcccccc}
\hline & Japan & Canada & Netherlands & UK & US & Australia \\
\hline DB & $95 \%$ & $95 \%$ & $94 \%$ & $82 \%$ & $39 \%$ & $14 \%$ \\
\hline DC & $5 \%$ & $5 \%$ & $6 \%$ & $18 \%$ & $61 \%$ & $86 \%$ \\
\hline Assets US\$ bn. & 3,386 & 1,924 & 1,690 & 3,451 & 29,196 & 2,077 \\
\hline
\end{tabular}

\section{Longevity}

By 17th June 2020 there were 8,006,427 confirmed cases of COVID-19 globally, including 436,899 deaths, reported to the World Health Organization (WHO 2020). The death of many members and pensioners from COVID-19 has reduced the liabilities of DB pension schemes, as the deceased will not receive any pension payments. The death of a pensioner terminates their pension, leaving only a spouse's pension, which is usually half the full pension. The death of an active member results in a death-in-service payment, which is generally a lot less 
than the actuarial value of the pension they would otherwise have received. Similarly insurance companies, who sell annuities mainly to former members of DC schemes, will also benefit. The death of an annuitant terminates the annuity payments, although survivor benefits (e.g. spouses) may continue at a much reduced rate. The size of these beneficial effects of COVID-19 for DB pension schemes and insurance companies is unclear. There may be repeat waves of $\mathrm{CO}$ VID-19 infection, and increased deaths from other causes indirectly caused by COVID-19, e.g. the temporary withdrawal of treatment for some medical conditions, people not seeking medical treatment due to the fear of contracting COVID-19, the damage caused by COVID-19 to the health of those who have recovered shortening their longevity, etc. Cairns et al (2020) modelled the likely effects of COVID-19 on UK longevity, and concluded that the main effect is to advance the date of death by a few years, e.g. people who would otherwise have died at age 85 , are dying at the age of 80 (40\% of deaths from COVID-19 in the UK were aged over 85). The implication of this model is that the beneficial effect of COVID-19 for DB schemes and annuity providers from the elevated death rate is small; and makes little difference to the funding of DB schemes and the price of annuities. In short, UK mortality has been declining over time, but COVID-19 has increased it to its level in 2008.

\section{State Pensions}

State pension schemes often have unique and complicated designs. Many state pensions, e.g. the UK, are pay-as-you-go with contributions by current employers and employees used to pay current pensions. Other state pensions are funded, and invest the contributions to pay the promised state pensions at a later date, e.g. China. COVID-19 has affected state pensions in a variety of ways.

Following COVID-19, the Finnish government temporarily reduced the employers' state pension contribution rate by $2.6 \%$ until the end of 2020, and will finance this using a reserve fund. The reduction in contributions will be recouped from employers by increasing their contribution rate for 2022-25. COVID-19 may lead to reductions in US Social Security benefits, as they are based on the US average wage index. Biggs (2020) has forecast that COVID-19 will automatically reduce US Social Security expenditure. He has estimated that, if this index drops by 15\% in 2020, Social Security benefits for those aged 60 in 2020 will be around 13\% per year lower when they retire. This will lower the cost of US Social Security and extend the date when it runs out of money to beyond 2034 (OASDI Trustees 2020). However, the large increase in the US unemployment rate from 3.5\% in February 2020 to $14.7 \%$ in April 2020 has reduced total Social Se- 
curity contributions paid by employees and employers (US Bureau of Labor Statistics 2020). There has also been a small increase in Social Security payments, due to unemployed workers retiring early. These effects may bring the date of exhaustion of the Social Security fund forward to 2029 (Gladstone, Akabas 2020).

The very large cost of COVID-19 to governments, in terms of supporting individuals and companies, and the drop in tax revenues from the reduction in economic activity may have a negative effect on the level of state pensions as governments seek to offset the costs of COVID-19. Since 2011 the UK has had a "triple lock" on annual increases in the state pension; which must rise by at least the highest of inflation, average earnings growth and 2.5\%. The Social Market Foundation has estimated that removing $2.5 \%$ to leave a "double lock" would save the government $£ 4$ billion per year (Corfe 2020).

Since over eight million UK workers have been furloughed on $80 \%$ of their wages, average earnings are forecast by the Office for Budget Responsibility (OBR 2020) to drop by 7.3\% in 2020. So state pensions will rise by the guaranteed minimum of $2.5 \%$. For 2021, after the furlough has ended, average earnings should rise by $7 / 93=8 \%$, while the OBR has forecast they will increase by $18.3 \%$. If this OBR forecast is correct state pensions will also rise by $18 \%$, unless the rules are changed.

Some governments have set aside a specific revenue stream, e.g. North Sea oil, to create a sovereign wealth fund to provide for state pensions (e.g. Norway, Chile, Ireland, France, China). Governments seeking to fund their COVID-19 expenditure and loss of revenue may draw money from their sovereign wealth fund. Norway has a $\$ 1,000$ billion sovereign welfare fund (the Government Pension Fund Global, GPFG) which receives government revenues from North Sea oil. Due to the pressures on government finances caused by COVID-19, the 2020 Norwegian budget has been amended, and instead of paying $\$ 0.4$ billion into the GPFG, the Norwegian government will withdraw $\$ 38$ billion from the fund. Further withdrawals from the GPFG may be needed in subsequent years. In France, as well as suspending major pension reform due to COVID-19, the French Pension Reserve Fund (FRR) will pay at least an additional $€ 13$ billion to help finance state pensions.

\section{Asset Values}

COVID-19 and the associated economic disruption has led to dramatic falls in stock markets around the world. From 12th February 2020 to 23rd March 2020 the FTSE 100 and S\&P 500 indices both fell by $34 \%$, although they then rose. As DB and DC pension funds hold large amounts of equities, this caused big reductions in the value of the 
assets available to pay pensions. During the first quarter of 2020 the value of US DB pension assets dropped by $14.9 \%$, and the value of UK DB pension assets dropped by 19.7\% (Evestment 2020). For DB schemes this led to a deterioration in their funding ratios (i.e assets/liabilities); while the pension pots of DC scheme members became smaller.

If $\mathrm{DB}$ schemes have a deficit they need to eliminate it over a number of years, usually by additional contributions. Higher contribution rates will put extra financial pressure on employers, leading them to reduce their dividends, investment, and other discretionary expenditure. There may also be an increase in the contribution rate for members, reducing their disposable income and incentivising them to leave the pension scheme and become deferred pensioners. For DC members the drop in asset values has reduced the expected size of their pension pot at retirement, which may mean they need to work longer before they can afford to retire.

The drop in equity prices caused by COVID-19 may be a short term phenomenon having little long term effect, with DB scheme funding and the value of DC pension pots recovering to their pre-COVID-19 levels. However, even if this happens, there will be losers. In some countries active members of DC schemes are allowed to withdraw money from their pension pot before they retire. Those members who transfer out of a DB scheme, or who cash in part of their DC pension pot before asset values recover, will be losers. To prevent this the Canadian government has placed a temporary ban on pension transfers and the purchase of annuities (Government of Canada 2020). In the UK DB scheme members can transfer their accumulated benefits to a DC scheme and, if they are over the age of 55, withdraw some or all of the money in their new DC pension pot. Transferring out of a DB scheme when asset values are depressed results in a low valuation of the member's accumulated pension benefits (the cash equivalent transfer value) that are transferred to the DC scheme, and therefore a poor deal for the member.

Australia has allowed unemployed members to remove $\$ 20,000$ from their pension pot, leading to a sharp increase in withdrawals. The US CARES Act 2020 allows DC scheme members to withdraw up to $\$ 100,000$ from their pot without penalty (Anzalone 2020), and 30\% of US DC scheme members have withdrawn money from their pension pots since the COVID-19 pandemic (Berger 2020). Iceland has allowed withdrawals from pensions of up to $€ 75,000$, regardless of age. While helping to deal with the immediate pressures of COVID-19 on household budgets, withdrawals reduce the size of pension pots available to finance retirement. It also means members are liquidating their pension assets when values are low. 


\section{Discount Rate}

COVID-19 has resulted in cuts in interest rates to exceptionally low levels, e.g. the Bank of England rate went from $0.75 \%$ on 11th March 2020 to only $0.10 \%$ on March 19, 2020. Cuts in interest rates reduce the discount rate used to compute the present value of DB scheme liabilities, leading to larger liabilities and reductions in scheme funding ratios. This may result in higher pension contributions being required from employers and members, and members leaving or declining to join DB schemes due to the higher cost.

Most DB scheme members in the UK and US are in the public sector (e.g. civil servants, armed forces, police, teachers, NHS, fire fighters). Almost all these UK schemes are unfunded, and contributions are set using the forecast rate of UK economic growth to discount the liabilities. It is widely forecast than COVID-19 will result in a substantial drop in long-term economic growth rates, with negative growth in the short run. This will increase the liabilities of unfunded public sector schemes, requiring higher contributions by public sector employers and scheme members.

\section{Companies}

By June 9, 20208.9 million workers in the UK had been furloughed (i.e. supported by the government not to work), and 2.5 million selfemployed workers were also being supported by the government (BBC 2020). A further 2.1 million were claiming unemployment benefits in April 2020 (ONS 2020). The UK pensions regulator has allowed employers to defer making their agreed deficit repair contributions to restore the funding of their DB schemes for three months or longer, on condition they do not pay any dividends during the deferment period and receive agreement from their trustees. This offer has been taken up by more than $10 \%$ of UK DB schemes. UK schemes are also free to alter the employer's contribution rate for DB and DC schemes, provided the scheme rules are followed; and Deloitte and the Financial Times have substantially reduced their DC contribution rates on a temporary basis. Only 15\% of UK DB schemes plan to make up for these temporary reductions in contributions by making additional contributions in the future (Willis Towers Watson 2020a). Most UK DB schemes are cash flow negative, so suspending employer contributions may increase the sale of assets at depressed prices. Cuts in dividends will also reduce the income received by pension funds on their equity holdings, e.g. Royal Dutch Shell has cancelled its $£ 2$ billion dividend. Given the financial pressures on employers, the UK pensions regulator will not pursue employers who are late in making their pension contributions; although 
it will pursue employers who do not pass on the member contributions deducted from salaries.

Due to the financial pressures on employers from COVID-19, employers in the Netherlands have been allowed to delay making their contributions to DB schemes, as have those in Bulgaria; while German employers have been allowed to delay making DB deficit repair contributions until 2021. Finland has also allowed employers to suspend contributions by themselves and their employees to occupational schemes for up to three months, and US employers have reduced or suspended their contributions to DC schemes (Mitchell 2020). In order to reduce their workforce due to the economic effects of COVID-19 on their revenue, some companies may offer early retirement on more generous terms. Providing these enhanced terms will deplete the funding of DB schemes.

The lockdown and associated drop in income will result in corporate failures. For those firms with DB pension schemes, this may mean their DB scheme has a deficit, and is unable to meet its pensions promise. In some counties such schemes enter a government authorised compensation scheme such as the Pension Protection Fund in the UK, and the Pension Benefit Guarantee Corporation in the US. COVID-19 will put pressure on the finances of these compensation schemes, and this will probably lead to an increase in the levies they impose on DB schemes.

\section{Members}

Most of those made unemployed by COVID-19 will probably become deferred pensioners, or perhaps transfer their pension to another scheme. Oku (2020) has estimated this will increase the number of dormant pensions in the UK by $32 \%$, and the deferred pensioners may lose track of these pensions. Older people who are made unemployed may decide to retire and start collecting their DB pension, or cash in their DC pension pot, while still looking for work. This will reduce the size of their annual DB or DC pension because they will be retired for longer. For those who continue to be employed, pressure on household finances and the possibility of higher contribution rates has meant that three million UK members of DC schemes have reduced or stopped their contributions, which will reduce the size of their pension pots at retirement. Similarly in the US, $47 \%$ of DC scheme members have lowered or stopped their contributions (Berger 2020).

The UK pension freedoms of 2015 brought the UK into line with other counties by allowing DC pensioners to invest their pension pot themselves, rather than buy an annuity with a guaranteed income when they retired. These pensioners in drawdown have suffered a sharp drop in their wealth as a result of the drop in asset values cau- 
sed by COVID-19. By giving members much more choice over their pensions, pension freedoms have permitted an increase in pension scams, and COVID-19 has led to a big increase in such scams. In May 2020 Canada Life (2020) found that since the COVID-19 outbreak began pension scams in the UK have risen by about $40 \%$, with one million people being targeted. This has reduced the pension assets of the victims, making them more likely to experience poverty in retirement. Many other counties have also warned against pension scams in connection with COVID-19.

COVID-19 may lead to runaway inflation (Amundi 2020). In the UK all DB pensions are required to be indexed to inflation up to $2.5 \%$, and some annuities are also inflation indexed. To the extent that DB pensions and annuities are subject to limited price indexation, since asset prices tend to increase with inflation, DB schemes should be protected or even gain. But pensioners will be losers, as their pensions will rise by less than inflation, reducing the real value of their pension for the rest of their retirement.

\section{Regulation}

The response of pension regulators has differed across countries in terms of suspending employer and member contributions, allowing members to access their pension assets, and the relaxation of other regulations. The US CARES Act has suspended the requirement for DC pensioners over the age of 72 to make minimum withdrawals from their pension pot. The UK has relaxed its insolvency laws and now restricts the right of creditors to recover debts, which reduces the ability of DB schemes and the Pension Protection Fund to pursue employers for unpaid pension contributions. Due to fears that foreign investment by Icelandic pension funds would devalue the krona, the central bank asked them to refrain from making foreign investments from March 2020 until September 2020. Regulators who have suspended rules (e.g. employer contributions, member pension withdrawals, insolvency), extended deadlines (e.g. actuarial valuations, reports to the pension regulator) and tolerated rule breaches, as well as placed restrictions on some activities (e.g. paying dividends, discouraging transfers from DB schemes), must decide when and how to restore the rules and their enforcement to pre-COVID-19 levels.

\section{Conclusions}

While COVID-19 has clearly had a negative short run effect on pensions, most of these negative effects should largely disappear in the long run, depending on the speed and extent to which the economy, 
asset prices and interest rates recover to pre-COVID-19 levels. Those who transferred out of a DB scheme, or who cashed in their DC pot during the period when asset prices were depressed, are losers. Employers who fail as a result of COVID-19 may have underfunded DB schemes, and the pension compensation schemes usually replace most, but not all, of the promised pension. Therefore the members (but not the pensioners, as they are usually fully compensated) of these DB schemes will also be losers, as will victims of the increased level of pensions fraud stemming from COVID-19. Pensions regulators face difficult decisions about when to end their forbearance, and require employers to revert to pre-COVID-19 regulations and contributions. They will also need to address the time scale over which employers are required to make their deferred contributions. Unless there is an upsurge in deaths from COVID-19, the benefit to DB pensions and annuity providers from the temporary increase in elderly mortality will have little short term effect on DB pension schemes, and no long term effect.

\section{Bibliography}

Amundi (2020). "Inflation: Persistent Headwinds but a Possible Inflationary Cocktail". Amundi, 9 June. https://bit.ly/39qYFvF.

Anzalone, J. (2020). "Retirement Plan Provisions in the Coronavirus Stimulus Bill". River and Mercantile Solutions, 29 March. https://bit.ly/2D3uFts.

BBC (2020). "More Than One in Four UK Workers Now Furloughed". BBC, 9th June. https://www.bbc.co.uk/news/business-52977098.

Berger, S. (2020). "3 in 10 Americans Withdrew Money from Retirement Savings Amid the Coronavirus Pandemic - and the Majority Spent it on Groceries". MagnifyMoney, 13 May. https://www.magnifymoney.com/blog/ news/early-withdrawal-coronavirus/.

Biggs, A.G. (2020). "How the Coronavirus Could Permanently Cut Near-Retirees' Social Security Benefits". PRC WP2020-6, April. https://repository.upenn.edu/prc_papers/675/.

Cairns, A.; Blake, D.; Kessler, A.; Kessler, M. (2020). "The Impact of COVID-19 on Future Higher-Age Mortality". The Pensions Institute. https://openaccess.city.ac.uk/id/eprint/24218/.

Canada Life (2020). "5.2 million UK Adults Either a Victim or Know Someone Who Has Fallen Victim to a Scam Since the Outbreak of Covid-19". Canada Life, 29 May. https://bit.ly/39nGgjh.

Corfe, S. (2020). "Intergenerational Fairness in the Coronavirus Economy". Social Market Foundation Briefing Paper, 14 April. https://www.smf.co.uk/ publications/intergenerational-fairness-coronavirus/.

Evestment (2020). US and UK Public Plan Asset Allocation: Opportunities for Asset Managers in the Public DB Space. April. https://bit.ly/3eRqz4Y.

Gladstone, N.; Akabas, S. (2020). "COVID-19 May Deplete Social Security Trust Funds This Decade". Bipartisan Policy Centre Report, 22 April. https:// bit.ly/2Br4L2j. 
Government of Canada (2020). "OSFI Actions to Address Issues Stemming from COVID-19”. 27 March. https://www.osfi-bsif.gc.ca/Eng/pp-rr/pparra/Pages/Pen20200327_let.aspx

Mitchell, O.S. (2020). "Building Better Retirement Systems in the Wake of the Global Pandemic". PRC WP2020-08, June. https://repository.upenn. edu/prc_papers/677/.

OASDI Trustees (2020). The 2020 Annual Report of the Board of Trustees of the Federal Old-Age and Survivors Insurance and Federal Disability Insurance Trust Funds. US Government Publishing Office. https://www.ssa.gov/ OACT/TR/2020/index.html.

OBR, Office for Budget Responsibility (2020). Commentary on the OBR Coronavirus Reference Portfolio. https://obr.uk/?s=earningst.

Oku, R. (2020). "Number of Dormant Pensions Set to Exceed 20m in 2020 Owing to Coronavirus". PensionBee, 3 June. https://www.pensionbee.com/ press/dormant-pensions-to-exceed-20m-in-2020.

ONS, Office for National Statistics (2020). "Claimant Count: K02000001 UK: People: SA: Thousands". 19 May. https://bit.ly/2WVjla1.

Sutcliffe, C.M.S. (2016). Finance and Occupational Pensions: Theories and International Evidence. London: Palgrave Macmillan. http://doi. org/10.1057/978-1-349-94863-5.

US Bureau of Labor Statistics (2020). "Labor Force Statistics from the Current Population Survey". https://data.bls.gov/timeseries/ LNS140000000.

WHO, World Health Organization (2020). WHO Coronavirus Disease (COVID-19) Dashboard. https://covid19.who.int/?gclid=EAIaIQobChMI_q_ T94re6QIVRevtCh10YwOwEAAYASAAEgJNIPD_BwE.

Willis Towers Watson (2020a). "Survey: Only 1-in-7 UK DB Schemes Say Additional Cash is the Answer". Willis Towers Watson, 20 May. https://bit. ly/2ZW8XAt.

Willis Towers Watson (2020b). "Global pension Assets Study 2020”. February. https://bit.ly/3eWZcq4. 